\title{
Soil Organic Carbon and Nitrogen Decomposition in Fecal Manure of Cattle Fed Browse/Maize Silages
}

\author{
Habib Kato ${ }^{1}$, Robert Mulebeke ${ }^{1}$, Felix Budara Bareeba ${ }^{2} \&$ Elly Nyambobo Sabiiti ${ }^{2}$ \\ ${ }^{1}$ Department of Agriculture, Kyambogo University, Kyambogo, Uganda \\ ${ }^{2}$ Department of Agricultural Production, Makerere University, Kampala, Uganda \\ Correspondence: Habib Kato, Department of Agriculture, Kyambogo University, Kyambogo, Uganda. E-mail: \\ habibkyanda@yahoo.co.uk
}

Received: January 7, 2014 Accepted: June 8, 2014 Online Published: June 15, 2014

doi:10.5539/sar.v3n3p50 URL: http://dx.doi.org/10.5539/sar.v3n3p50

\begin{abstract}
Soil organic carbon (C) and nitrogen $(\mathrm{N})$ decomposition in fecal manure of cattle fed browses of Calliandra (Calliandra calothyrsus), Gliricidia (Gliricidia sepium) and Leucaena (Leucaena leucocephala) browse/maize silage mixtures and maize (Zea mays) silage alone when applied to the soil were investigated in a pot experiment in comparison to the corresponding silages fed. Maize silage alone had the lowest $\mathrm{N}$ and a larger $\mathrm{C}: \mathrm{N}$ ratio, making it a poor quality compost when applied to the soil, but compared to the browse/maize silage mixtures it had the highest level of soluble $\mathrm{N}$ as non-protein nitrogen (NPN) which makes much of its $\mathrm{N}$ available for soil microbial decomposition of its organic C. Calliandra browse/maize silage mixture had the highest level of fiber-bound $\mathrm{N}$ (ADFN), which reduces $\mathrm{N}$ availability for soil microbial decomposition of its organic $\mathrm{C}$ in spite of its high $\mathrm{N}$ content and a narrower $\mathrm{C}: \mathrm{N}$ ratio. Fecal manure from maize silage alone had a lower level of $\mathrm{N}$ and a wider $\mathrm{C}$ : $\mathrm{N}$ ratio than fecal manure from the other silages fed which would affect its decomposition in the soil, but it had the lowest level of ADFN and much of its $\mathrm{N}$ is made available for soil microbial decomposition of its organic C. Soil samples after 12 weeks of the experiment showed that Calliandra browse/maize silage mixture maintained the highest level of $\mathrm{C}$ in the soil, while maize silage alone maintained the lowest level. Also soils treated with fecal manure from the other browse/maize silage mixtures maintained higher levels of $\mathrm{C}$ than fecal manure from maize silage alone. Organic $\mathrm{C}$ levels were lowest at 8 weeks of the experiment for all treatments and rose to the original levels at 12 weeks which could have been as a result of biotic and hydrologic factors coupled with soil aggregation. Decomposition of organic $\mathrm{N}$ followed a similar trend as organic $\mathrm{C}$. The two elements are linked in both plant inputs in the soil and in the eventual soil humic substances. The soils treated with browse/maize silage mixtures maintained $\mathrm{C}$ : $\mathrm{N}$ ratios that were similar to that of the control soil and higher than those of the fecal manure treatments. Thus, in spite of the added silage materials to the soil, rapid decomposition of organic $\mathrm{C}$ could not occur to reflect benefits of adding the silage materials to the soil. Thus, fecal manure, particularly from feeding animals on browse/forage diets is more beneficial in the soil as it would decompose more readily releasing the plant nutrients they contain.
\end{abstract}

Keywords: browse, aggregation, silage, Calliandra, Gliricidia, Leucaena

\section{Introduction}

Soil fertility depletion is a major problem affecting agricultural production and food security in small holder farming systems in Sub-Sahara Africa (Stoorvegel et al., 1993 as cited by Zake et al., 2010). The farming practices being used can not ultimately sustain soil fertility and productivity. In these farming systems, soil fertility depletion is particularly due to continuous crop harvest without due replenishment, soil erosion, burning of bushes and crop residues (Olson \& Berry, 2003 as cited by Zake et al., 2010). Livestock manures, have been exploited in restoring soil fertility in Uganda (Twinasiko, 2001; Kajura, 2001). Cattle manure in particular, is an appropriate resource because it is readily available on farm and affordable by small holder farmers (Zake et al., 2010) and it enhances the physical, chemical and biological properties of the soil. Elephant grass (Panisetum purpureum) is promoted for stall feeding of cattle often supplemented with browse forages (Sabiiti, 2001). It is also a common and popular practice to ensile elephant grass with Calliandra (Calliandra calothyrsus). Leucaena (Leucaena leucocephala) or Gliricidia (Gliricidia sepium) browses in smallholder zero-grazing units in Uganda. The release of nutrients in the fecal manure in the soil depends not only on the type of feed material fed to the 
animals but also, the composition of the material fed influences the rate of decomposition both in the rumen and the soil. Calliandra and Leuceana browses have substantial levels of tannins and lignin (Bareeba and Aluma, 2000) which bind protein and protect it from degradation in the rumen (Fahey et al., 1980; Navas-Comancho et al., 1993). Browses high in polyphenols are likely to give manure rich in lignin, neutral detergent insoluble $\mathrm{N}$, and feacal-insoluble N. In the soil, low quality organic materials are first immobilized then later mineralized to release nutrients. The effect of rumen decomposition on browse materials and the subsequent release of nutrients from fecal manure to the soil is not adequately documented. The purpose of this study was to investigate the decomposition of organic Carbon (C) and Nitrogen (N) in fecal manure from cattle fed on Calliandra, Gliricidia and Leucaena browse/maize silage mixtures and maize silage alone when applied to the soil.

\section{Materials and Methods}

\subsection{Experiment Set-Up and Design}

The silages and fecal manure used in the experiment were obtained from a 12 week feeding trial experiment with dairy cattle. The silages fed were a mixture of browses and maize (20\% browse on DM basis) and maize silage alone. The browses were Calliandra (Calliandra calothyrsus), Gliricidia (Gliricidia sepium) and Leucaena (Leucaena leucocephala) and the maize (Zea mays) used was whole plant with cobs, the crop having reached milk stage, about 25\% DM. The silages and fecal manure obtained were air dried, aggregated and ground in a laboratory mill to pass through a $2 \mathrm{~mm}$ sieve before application to the soil. Samples of the silages and fecal manure were saved for laboratory analysis. The soil used in the experiment was collected from a crop field. The soil was spread out in a screen house to dry after which it was ground to pass through a $2 \mathrm{~mm}$ sieve and mixed thoroughly. A sample of the soil was saved for laboratory analysis. The experiment was carried out as a pot experiment in a screen house. Four kilograms of soil were used in each pot. The fecal manures and silages were applied to the soil at the rate of $5 \mathrm{~g} / \mathrm{kg}$ of soil, which was equivalent to the rate of manure application of $10 \mathrm{t} / \mathrm{ha}$ for 3 years for Uganda, each hectare being equivalent to a plough share of 2,000,000 $\mathrm{kg}$ of soil (Anderson and Ingram, 1993; Ssali, 2001). There was no crop planted in the pots. Moisture content was kept at field capacity by watering as and when watering of the pots for a related experiment was done. The study was set up in a completely randomized block design (CRBD) with four treatments comprising of; Calliandra/maize, Gliricidia/maize, Leucaena/maize and maize. The treatments were put in two blocks i.e. silages and fecal manure. The treatments were replicated four times.

\subsection{Preparation of Samples}

Soil samples for measurement of $\mathrm{C}$ and $\mathrm{N}$ were taken in four successive cycles at intervals of four weeks. The soil samples collected were air dried in the laboratory and ground to pass through a $2 \mathrm{~mm}$ sieve and saved for chemical analysis.

\subsection{Chemical Analysis of the Silage, Fecal Manure and Soil Samples}

Organic C was analysed following the procedures by Walkley and Black (1993) and total N by the Kjeldah method (AOAC, 1990). Non-Protein Nitrogen (NPN) was determined by the trichloro acetic acid method (Gaines, 1977) and Acid Detergent Fiber Nitrogen (ADFN) was determined by analyzing for total nitrogen in the ADF residue. The ADF residue was obtained by the Van Soest and Robertson (1985) procedures.

\subsection{Data Analysis}

The data obtained was subjected to statistical analysis by Genstat Release 12.2 and differences between the means were separated using the Least Significant Difference (LSD) method at probability level of 5\%.

\section{Results and Discussion}

\subsection{Chemical Composition of the Silages and Fecal Manures}

The $\mathrm{C}$ and $\mathrm{N}$ composition of the silages and fecal manures used in the experiment are shown in Table 1. The composition of the silages is as a result of fermentation during the ensiling process of the silages, while composition of the fecal material is greatly influence by passage of the feed material through the digestive tract of the animals. 
Table 1. Carbon and Nitrogen composition of the browse/maize silage mixtures (20\% browse DM basis) and corresponding fecal manures applied to the soil

\begin{tabular}{cccccccccc}
\hline & \multicolumn{4}{c}{ Browse/Maize Silages } & \multicolumn{4}{c}{ Fecal Manure } \\
\hline Composition & Call & Glir & Leuc & Maize & Call & Glir & Leuc & Maize \\
Carbon (\%DM) & 46.47 & 46.23 & 45.82 & 46.32 & 41.99 & 40.1 & 40.84 & 41.09 \\
Nitrogen (\%DM) & 1.7 & 1.9 & 1.87 & 1.28 & 2.27 & 2.05 & 2.28 & 1.8 \\
NPN (\% Total N) & 21.95 & 34.71 & 27.02 & 41.28 & 19.13 & 18.43 & 14.58 & 12.84 \\
ADFN(\% Total N) & 24.82 & 11.58 & 14.42 & 16.14 & 25.42 & 19.97 & 26.11 & 15.64 \\
C: N Ratio & 27.34 & 24.33 & 24.5 & 36.19 & 18.5 & 19.56 & 17.91 & 22.83 \\
\hline
\end{tabular}

Call - Calliandra; Glir - Gliricidia; Leuc - Leucaena.

The browse/maize silage mixtures and maize silage alone had comparable levels of $\mathrm{C}$. However, maize silage alone had the lowest amount of $\mathrm{N}$ and the widest $\mathrm{C}: \mathrm{N}$ ratio, which explains its low decomposition rate when applied to the soil as compost. Low $\mathrm{N}$ available in relation to the $\mathrm{C}$ retards growth and activity of soil micro organisms that decompose the organic material. On the other hand, maize silage had the highest level of soluble $\mathrm{N}(\mathrm{NPN} \%$ of Total $\mathrm{N}$ ) which is made available to the soil micro-organisms and therefore supports decomposition of the organic matter. Of the browse/maize silage mixtures, Calliandra/maize silage mixture had the highest level of fiber-bound $\mathrm{N}$ (ADFN). The high level of ADFN reduces available $\mathrm{N}$ to the soil micro-organisms and therefore, affect the decomposition of Calliandra/maize silage mixture organic matter in the soil.

All the fecal manures had comparable levels of $\mathrm{C}$ and $\mathrm{N}$ except fecal manure from maize silage alone, which had a lower level of $\mathrm{N}$ and corresponding wider $\mathrm{C}: \mathrm{N}$ ratio as with the maize silage alone. Thus, the decomposition in the soil of the fecal manure from maize silage alone could be affected by its low level of $\mathrm{N}$, a wider $\mathrm{C}$ : $\mathrm{N}$ ratio and lower level of available N (NPN \% Total N). However, the fecal manure from maize silage alone had the lowest level of ADFN, and therefore much of its $\mathrm{N}$ is made available to the soil micro-organisms that decompose the manure. The fecal manures from the browse/maize silage mixtures although with different browses of Calliandra, Gliricidia and Leucaena would be expected to be decomposed to the same extent by the soil micro-organisms because of having comparable levels of $\mathrm{C}, \mathrm{N}$ and soluble $\mathrm{N}$ or their decomposition would be inhibited to the same extent because of having similar levels of ADFN and C:N ratios.

\subsection{Decomposition of Organic Carbon and Nitrogen}

The mean levels of $\mathrm{C}$ in the soil treated with browse/maize silage mixtures and their corresponding fecal manures for three successive sampling cycles of four weeks each are shown in Table 2.

Table 2. Soil carbon and nitrogen in soils treated with browse/maize silage mixtures and corresponding fecal manures

\begin{tabular}{|c|c|c|c|c|c|c|c|c|c|c|}
\hline & \multirow{3}{*}{$\begin{array}{c}\text { Control } \\
\text { Soil }\end{array}$} & \multicolumn{9}{|c|}{ Soil Treatment } \\
\hline & & \multicolumn{4}{|c|}{ Browse/Maize Silage Mixture } & \multicolumn{5}{|c|}{ Fecal Manure } \\
\hline & & Call. & Glir. & Leuc. & Maize & Call. & Glir. & Leuc. & Maize & LSD \\
\hline Carbon (\%) & $1.21^{\mathrm{d}}$ & $1.47^{\mathrm{a}}$ & $1.36^{\mathrm{b}}$ & $1.36^{\mathrm{b}}$ & $1.27^{\mathrm{c}}$ & $1.30^{\mathrm{bc}}$ & $1.32^{\mathrm{b}}$ & $1.35^{\mathrm{b}}$ & $1.29^{\mathrm{c}}$ & 0.09 \\
\hline Nitrogen $(\%)$ & $0.123^{\mathrm{c}}$ & $0.143^{\mathrm{a}}$ & $0.131^{\mathrm{b}}$ & $0.133^{\mathrm{b}}$ & $0.134^{\mathrm{b}}$ & $0.136^{\mathrm{b}}$ & $0.134^{\mathrm{b}}$ & $0.133^{\mathrm{b}}$ & $0.133^{\mathrm{b}}$ & 0.006 \\
\hline C:N Ratio & $9.85^{\mathrm{a}}$ & $10.27^{\mathrm{a}}$ & $10.37^{\mathrm{a}}$ & $10.22^{\mathrm{a}}$ & $9.71^{b}$ & $9.44^{\mathrm{b}}$ & $9.79^{b}$ & $10.38 \mathrm{a}$ & $9.79 \mathrm{~b}$ & 0.54 \\
\hline
\end{tabular}

Call - Calliandra; Glir - Gliricidia; Leuc - Leucaena.

${ }^{\text {abcd }}$ values having different superscripts in a row are significantly different $(P \geq 0.05)$.

The browse/maize silage mixtures and their corresponding fecal manure treatments maintained higher levels of $\mathrm{C}$ in the soil than maize silage alone and its corresponding fecal manure treatment. There was evidence of less decomposition of organic $\mathrm{C}$ in the soils treated with browse/maize silage mixtures and their corresponding fecal 
manures (Table 2). Although maize silage alone had less $\mathrm{N}$ than the browse/maize silage mixtures, much of its $\mathrm{N}$ was in the available form (NPN) which could have enhanced decomposition of its organic C in the soil. Similarly, although fecal manure from maize silage alone had less $\mathrm{N}$ than the fecal manures from browse/maize silage mixtures it had lower levels of fiber-bound $\mathrm{N}$ (ADFN), which factor would have otherwise rendered less $\mathrm{N}$ being available for microbial decomposition of the organic $\mathrm{C}$ in the fecal manure. Thus, organic $\mathrm{C}$ decomposition was greater in soils treated with fecal manure from maize silage alone.

Treatments with either silages or fecal manures maintained higher levels of $\mathrm{N}$ in the soil than the control soil. However, Calliandra browse/maize silage mixture and its corresponding fecal manure maintained highest levels of $\mathrm{N}$ in the soil. Calliandra browse/maize silage mixture had the lowest level of soluble N (NPN), the highest level of fiber-bound $\mathrm{N}$ (ADFN) and the widest $\mathrm{C}$ : $\mathrm{N}$ ratio, while the corresponding fecal manure also had the highest level of fiber-bound $\mathrm{N}$. These factors could have rendered Calliandra/maize silage mixture and its corresponding fecal manure less degradable and therefore maintained higher levels of organic $\mathrm{C}$ and $\mathrm{N}$ in the soil. Calliandra and Leucaena browses have substantial levels of tannins and lignin (Bareeba \& Aluma, 2000) which bind protein and protect it from degradation in the rumen or digestive tracts of grazing animals (Fahey et al., 1980; Navas-Comancho et al., 1993). The tannins and lignin could have further hindered degradation of organic $\mathrm{N}$ in the browse/maize silage mixtures and their corresponding fecal manures in the soil.

The narrow $\mathrm{C}: \mathrm{N}$ ratio in the fecal materials was due to passage of the feed materials of the browse/maize silage mixtures through the digestive tract except, in the case of Leucaena browse/maize silage mixture which maintained a similar $\mathrm{C}$ : $\mathrm{N}$ ration in the corresponding fecal manure. There are factors peculiar to Leucaena which limit its degradation in the digestive tracts of animals (Flores, et al., 1979; Jones \& Bray, 1982; Quirk, et al., 1988; Hammond, 1995; Kaitho, 1997). Therefore, the browse/silage mixtures unlike their corresponding fecal manures maintained higher $\mathrm{C}: \mathrm{N}$ ratios in the soil similar to that of the control soil. Thus they showed no benefit of their addition to the soil in spite of the watering of the soil that was being done. Rapid decomposition of organic carbon should have occurred when a dry soil is followed by watering (Russel, 1961; Parton et al., 1987 as cited by Young et al., 2012). The results show that fecal manures are more beneficial in the soil as they would be decomposed more readily because of their narrowed C: N ratios (Russel, 1961; Brady, 1974) and easily release the plant nutrients they contain in the soil.

The effect of sampling cycles indicated rapid organic $\mathrm{C}$ decomposition or decline in the soil that reached a minimum level at the second cycle of sampling, 8 weeks from start of the experiment. The $\mathrm{C}$ levels regained their original levels in the soil at the third cycle of sampling, 12 weeks of the experiment (Table 3).

Table 3. Effect of sampling cycles on overall Carbon and Nitrogen composition and C: $\mathrm{N}$ ratios in the soils treated with browse/maize silage mixtures, maize silage alone and corresponding fecal manures

\begin{tabular}{cccccc}
\hline Composition & Initial & 1 & 2 & 3 & LSD \\
\hline Carbon (\%) & $1.34^{\mathrm{a}}$ & $1.35^{\mathrm{a}}$ & $1.25^{\mathrm{b}}$ & $1.36^{\mathrm{a}}$ & 0.09 \\
Nitrogen (\%) & 0.133 & 0.134 & 0.132 & 0.133 & 0.006 \\
C:N Ratio & $10.20^{\mathrm{a}}$ & $10.03^{\mathrm{a}}$ & $9.47^{\mathrm{b}}$ & $10.27^{\mathrm{a}}$ & 0.54
\end{tabular}

${ }^{\mathrm{ab}}$ values having different superscripts in a row are significantly different $(\mathrm{P} \geq 0.05)$.

The sampling cycles had no significant effect on the $\mathrm{N}$ levels maintained in the soil by the treatments. However, the lowest level of $\mathrm{N}$ occurred with the second sampling cycle, 8 weeks from start of the experiment and rose to the original level at the third cycle of sampling, 12 weeks of the experiment. The rise in $\mathrm{C}$ levels lends credence to the rise in $\mathrm{N}$ levels in the soil, which could be due to the biotic synthetic activities that occur in the soil (Klaus, et al., 2012). Soil organic $\mathrm{N}$ changes are known to accompany any changes in soil organic carbon because the two elements are linked in both plant inputs and in eventual humic substances in the soil (Wander, 2004 as cited by Leon et al., 2006).

\section{Conclusion}

The results have indicated that addition of browse/maize silage mixtures to the soil maintains higher levels of organic carbon in the soil than maize silage alone implying that addition of forage materials mixed with browses to the soil maintains organic carbon in the soil for a longer period than forages alone. Similarly fecal manure obtained from feeding browse/forage diets to dairy cattle maintains organic carbon in the soil longer than fecal 
manure obtained from feeding forages alone. Besides, fecal manure has smaller and also maintain smaller C: $\mathrm{N}$ rations than the browse/forage or forage green manure or compost and, therefore a better quality manure. Passage of the forages through the digestive tract of grazing animals ameliorates the divergence in $\mathrm{N}$ fractions in the forage feeds.

\section{Acknowledgements}

This study was technically and financially supported by Kyambogo University, Uganda.

\section{References}

Anderson, J. M., \& Ingram, J. S. (1993). Tropical soil biology and fertility: A hand book of methods, Second Edition. C A B International, 82, 70-82.

AOAC. (1990). Official methods of analysis (15th ed.). AOAC Inc. Arlington, Virginia. USA.

Bareeba, F. B., \& Aluma, J. (2000). Chemical composition, phenolics and in vitro organic matter digestibility of some multipurpose tree species used for agroforestry in Uganda. Uganda Veterinary, 6, 89-92.

Brady, N. C. (1990). The Nature and Properties of Soil (pp. 257-258; 268-269). Macmillan Publishing Co.

Fahey, Jr. G. C., At-Haydari, S. Y., Hindis, F. C., \& Short, D. E. (1980). Phenolic compounds in roughages and their fate in the digestive system of sheep. J. Anim. Sci., 50, 1165-1172.

Flores, J. F., Stobbs, T. H., \& Minson, D. J. (1979). The influence of the legume Leucaena leucocephala and formal-casein on the production and composition of milk from grazing cows. J. Agric. Sc., Camb, 92, 351-357. http://dx.doi.org/10.1017/S0021859600062870

Gaines, T. P. (1977). Determination of protein nitrogen in plants. $A O A C$., 60, 590.

Hammond, A . C. (1995). Leucaena toxicosis and its control in ruminants. J. Anim. Sci., 73, 1487-1492.

Jones, R. J., \& Bray, R. A. (1982). Agronomic research in the development of Leucaena as a pasture legume in Australia, In Leacaena Research in the Asian-Pacific Region. Proceedings of a workshop held in Singapore, 23-26 November 1992.

Kaitho, R. J. (1997). Nutritive value of browses as protein supplement(s) to poor quality roughages. $\mathrm{Ph} \mathrm{D}$. Thesis, Landbrouw Universiteit, Wageningen.

Kajura, S. (2001). Beef Production. In J. K. Mukiibi (Ed.), Agriculture in Uganda, Fountain Publishers/National Agricultural Research Organization (NARO) Uganda, 4, 1-17.

Klaus, L., \& Rattan, L. (2012). Cropland soil carbon dynamics in Recarbonization of the Biosphere: Ecosystems and the Global Carbon Cycle. In L. Rattan, L. Klaus, F. H. Reinhard, S. Berd Uwe, Joachim von Braun (Eds.), pp. 303-346.

Leon, H. A. Jr., Stephen, L., Albrecht, S. L., Boote, K. J., Jean, M. G. T., Newman, J. C., \& Skirvin, K W. (2006). Carbon and nitrogen accumulation in plots of Rhizoma perennial peanut and Bahia grass grown in elevated carbon dioxide and temperature. Journal of Environmental Quality. ASA, CSSA and SSSA.

Navas-Camacho A, Max, A. L., Aurora, C., Hector, A., \& Juan, C. L. (1993). Effect of supplementation with a tree legume forage on rumen function. Livestock Research for Rural Development, 5(2).

Quirk, M. F., Bushell, J. J., Jones, R. J., Megrrity, R. G., \& Buttler, K. L. (1988). Live weight gains on Leucaena and native grass pastures after dosing cattle with rumen bacteria capable of degrading DHP, a rumenal metabolite. J. Agric. Sci. Camb, 3, 165. http://dx.doi.org/10.1017/S0021859600082976

Russell, W. (1961). Soil conditions and plant growth (9th ed.). Longmans, pp. 49, 249.

Sabiiti, E. N. (2001). Pastures and range management. In J. K. Mukiibi (Ed.) Agriculture in Uganda, Fountain Publishers/National Agricultural Research Organization (NARO) Uganda, 4, 237-297.

Ssali, H. (2001). Soil fertility. In J. K. Mukiibi (Ed.), Agriculture in Uganda. Fountain Publishers/National Agricultural Research organization (NARO) Uganda, 1: 104-135.

Twinamasiko, N. I. (2001). Dairy Production. In J. K. Mukiibi (Ed.), Agriculture in Uganda Fountain Publishers/National Agricultural Research Organization (NARO) Uganda, 4, 18-24.

Van Soest, P. J., \& Robertson, J. B. (1985). Analysis of forage and fibrous foods. A laboratory manual for Animal Science 613. Cornell University, Ithaca. New York, USA.

Walkley, A., \& Black, I. A. (1993). An examination of the detjareff method for determining soil organic matter 
and a proposed chromic acid titration method. Soil Science Journal, 34, 29-38.

Yang, L., Pan, J., Shao, Y., Chen, J. M., Ju, W. M., Shi, X., \& Yuan, S. (2007). Soil organic carbon decomposition and carbon pools in temperate and sub-tropical forests in China. Journal of Environment Management, 85, 690- 695. http://dx.doi.org/10.1016/j.jenvman.2006.09.011

Zake, J., Tenywa, J. S., \& Kabi, F. (2010). Improvement of manure management for crop production in central Uganda. Journal of Sustainable Agriculture, 34, 595-617. http://dx.doi.org/10.1080/10440046.2010.493368

\section{Copyrights}

Copyright for this article is retained by the author(s), with first publication rights granted to the journal.

This is an open-access article distributed under the terms and conditions of the Creative Commons Attribution license (http://creativecommons.org/licenses/by/3.0/). 